\title{
Cost of Poor Power Quality in Industrial Plants
}

\author{
Ozer Ergun ${ }^{1}$, Emel Onal ${ }^{2}$ \\ ${ }^{1,2}$ Istanbul Technical University, Electrical Engineering Department, Istanbul-Turkey
}

\begin{abstract}
Industrial enterprises are developing various energy efficiency-related projects, which are fundamentally divided into two groups, electrical and mechanical. The projects that are about electricity content; the use of efficient electric motors, the use of efficient lighting systems, the production of waste heat electricity, the quality of the electric energy used. In this paper, It is conducted a study on how much the electric energy used by industrial enterprises. In the content of the studies, some extraordinary situations have been observed at the parameters of power quality and its impact on cost of electric energy has been calculated.
\end{abstract}

Keywords: Power quality, energy efficiency, electrical systems.

\section{Introduction}

The studies on power systems are based on the fact that electricity is being used. These studies have increased especially in the 20th century and harmonics are the basis of these studies. Transformers are seen as the greatest harmonic source in this period. For this reason, many studies have been carried out on reducing the harmonics on the transformer [1].The developments in semiconductor technology have begun to be examined together with their power quality. A commission was established in 1991 by the IEEE to examine the sine wave form, which is now the basis of the analysis of power quality. The current, voltage and power expressions related to non-sinusoidal electrical systems are mathematically defined with the standard that this commission has prepared. In addition, the definitions that have caused the sinusoidal deterioration in the standard are both made and the mathematical expressions of these expressions are given.

Over time, this standard has been developed by specific working groups and has become a different boundary value and standard for each country [2]. The work and others have done in their entirety has examined the costs caused by deterioration in power quality in real time. The cost effectiveness of the parametric parameters affecting the power quality such as energy interruption, voltage collapse, harmonic, voltage fluctuations, transient formation are formulated and a sample work is done. In this study, the formulas are made simpler than the previous studies, and some basic measurements and values related to the system to be investigated are taken and studies are carried out about how much the energy quality is poor for the installation.La Commare and Eto have calculated the costs of the problems of power quality inhabitants from the reports of the international organizations and data of the countries[2].

Reports and data from organizations such as Electric Power Research Institute (ERPI), US Department of Energy (DOE) and Energy Information Administration (EIA) are used. All of these studies show that the cost of power poorness is 26 billion dollars in cost, and when the losses of consumers are taken into consideration, this lost is seen to reach 50 billion dollars. When calculating this cost, the region where the problem of power quality is present in the formula used, the frequency of the problem and the unit cost of the energy are used as parameters. The distribution of losses in power quality is in the form of industry, commerce and habitats.[3-4]. 


\section{Energy Quality}

Taking $\mathrm{P}=\mathrm{V} * \mathrm{I}$ as a power expression, the voltage and current appearances of the parameters that are effective in the expression of the electrical power. Energy is the basis of the quality of the voltage quality. The quality of the voltage is largely affected by the voltage of the network and the problems related to the voltage in the plant are caused by the network. When power quality is discussed in detail, two more parameters are emerging; Current and frequency. Unlike the tension on the current side, the poor quality is caused by the load on the plant side or in other words [5-6].

In this section, the measured values of these parameters exceed the limit values and the cost of the time that causes the poor quality of power are examined. This review; power interruptions, harmonic losses, voltage fluctuations, power factor.

The basis of power quality is constant, cheap and balanced energy concepts. The continuity of energy is of great importance in terms of energy quality and is the basis of the sustainability of the system. The industrial plant protects itself from energies by engaging the generators firstly at breaks in the big diameter. This situation causes large cost losses for the plant. According to IEEE 519 standards, the interruption is basically examined in two different ways: short interruptions, long interruptions[7].

Short interrupts are assumed to be composed of two components in this standard. Momentary interruptions (Half period - 3 seconds) and temporary interruptions (3 seconds - 1 minute). The cost caused by these discontinuities is examined in 3 basic topics. These are direct cost, restart cost,confidential cost.

The harmonics described in detail in the previous sections, which are usually caused by non-linear loads, cause great energy losses and care should be taken to keep them within the limit values. If the harmonics that are limited to certain standards in our country are exceeded, it causes energy losses due to serious problems related to equipments as well as fluctuations experienced in power parameters [8]. The costs of harmonics depends on the cost of energy losses and the cost of the device due to the decrease in the lifetime of the device.Energycost $\left(D_{l i}\right)$ causedbyharmonics is expressed in formula (1). $\mathrm{D}_{0}$ is the unit cost of energy, the current caused by the harmonics and the amount of increase in the amplitude at the bottom, and $\mathrm{G}_{\mathrm{h}}$ is the duration of the harmonic distortion that occurs outside the limit values. $\mathrm{E}_{t}$ is amount of increase of voltage and current.

$D_{l i}=D_{0} \cdot E_{t}\left(G^{h_{i}} \ldots G^{h_{\max }}\right)$

While calculating the amount of amplitude caused by the harmonics, the value of the current and the voltage at a certain time is found by subtracting from the pure sinusoidal wave expressed in formula (2).

$E_{t}=-\left(\int_{0}^{\Delta t} u_{1} \cdot i_{1} d t-\int_{0}^{\Delta t} u i d t\right)$

The first principal component of voltage is summed with all other components present, and the total voltage amplitude is found.Formula (3) referstothissituation.

$u=u_{1}+\sum_{h \neq 1}^{\infty} u_{h}(3)$

The first fundamental component of the current is summed with all the other components present, and the total current amplitude is found. Formula (4) refers to this situation.

$i=i_{1}+\sum_{h \neq 1}^{\infty} i_{h}$

From here, the cost of the device over its lifetime can be calculated.

The volatility fluctuations are also of great importance when the cost of short term interruptions is determined for industrial facilities. The effect on the cost of this volatility, which is described as the weight factor, is shown in table 1 [7].The cost caused by the voltage fluctuation is calculated as formula (5).

TABLE I: The Weight Factor Value Determined by Fluctuations in Voltage

\begin{tabular}{ll}
\hline \hline \multicolumn{1}{c}{ Event } & \multicolumn{1}{c}{ Weight Factor } \\
\hline Shortinterruption & $\mathrm{W}_{\mathrm{o}}=1$ \\
Voltagesurge (below 50\%) & $\mathrm{W}_{1}=0,8$ \\
Voltagesurge (50\% 70\%) & $\mathrm{W}_{2}=0,4$ \\
Voltagesurge (70\% 90\%) & $\mathrm{W}_{3}=0,1$ \\
\hline
\end{tabular}


$\sum C_{i}=C_{0} * P_{i} * w_{i}(5)$

Here, $C_{0}$ is the unit energy price and $P i$ is the amplitude of energy. In the form of a replacement cost account is made. Besides, the card faults due to the voltage fluctuation inside the plant are a hidden cost in problems that will arise in the engine driver[9-10].

\section{Investigational Facilities}

A total of 10 facilities operating in the sectors covered by four different sectorsare examined. A Fluke 435-II model energy analyzer is connected to the low voltage side of the distribution transformers of these plants and 12 hourly measurements of the parameters relating to power quality such as voltage, phase current, neutral voltage, neutral current, power consumption, power factor, voltage harmonics are obtained.These measurements are made in the Power Log program, the package program of the Fluke analyzer, and the measurements are analyzed both statistically and graphically. The four different sectors as food producers, building material producers, paper producers and oil producers are examined.The two variables as voltage and current are needed in the analyzer measurement principle. The 12 hours data is as following figures (fig1-fig6).

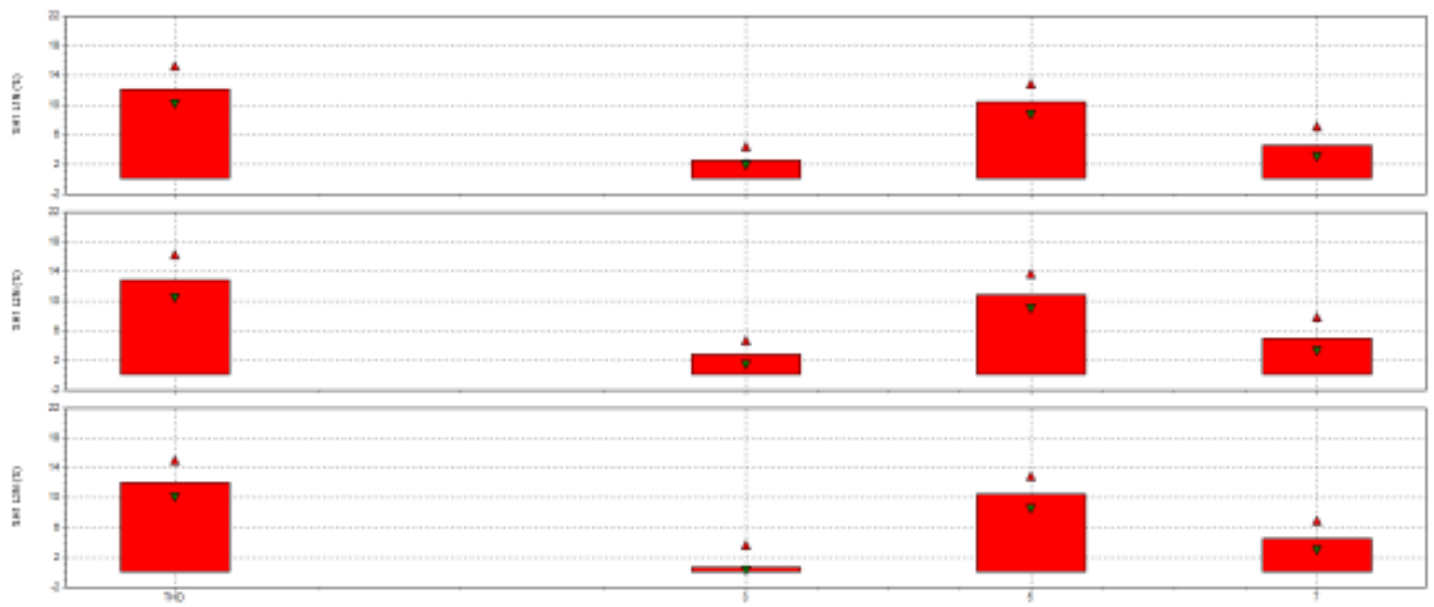

Fig. 1: Measurement of Current Harmonic

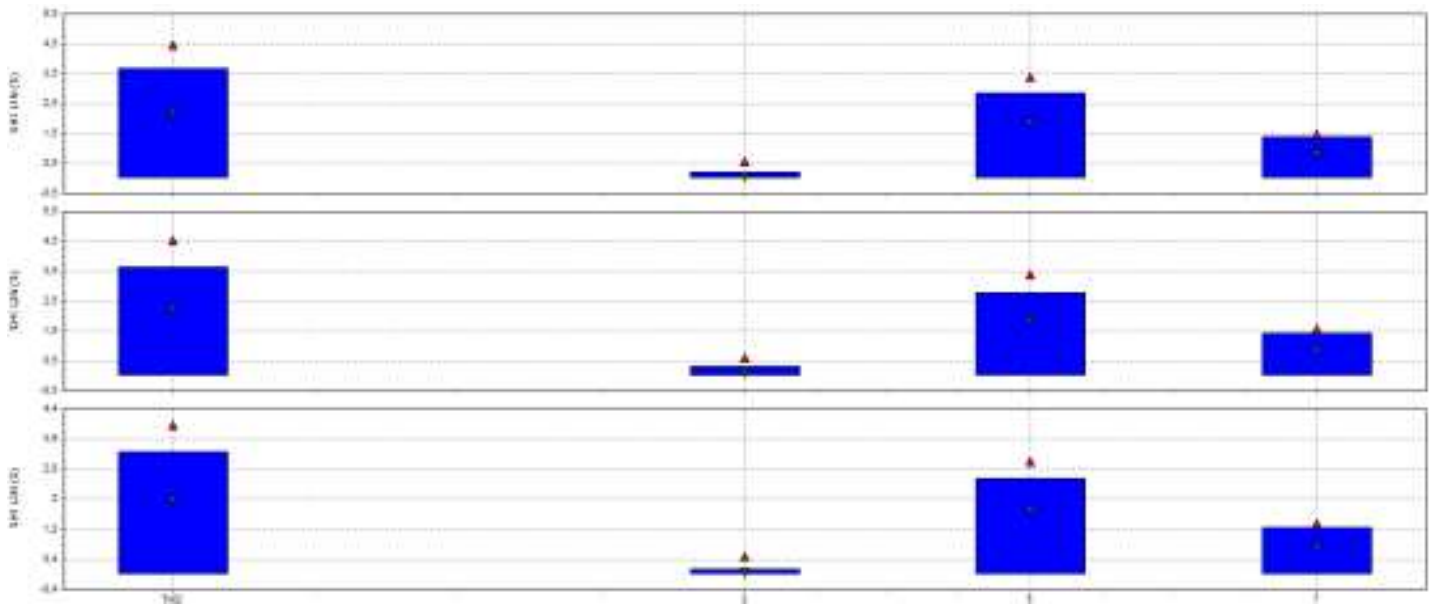

Fig. 2: Measurement of Voltage Harmonic 


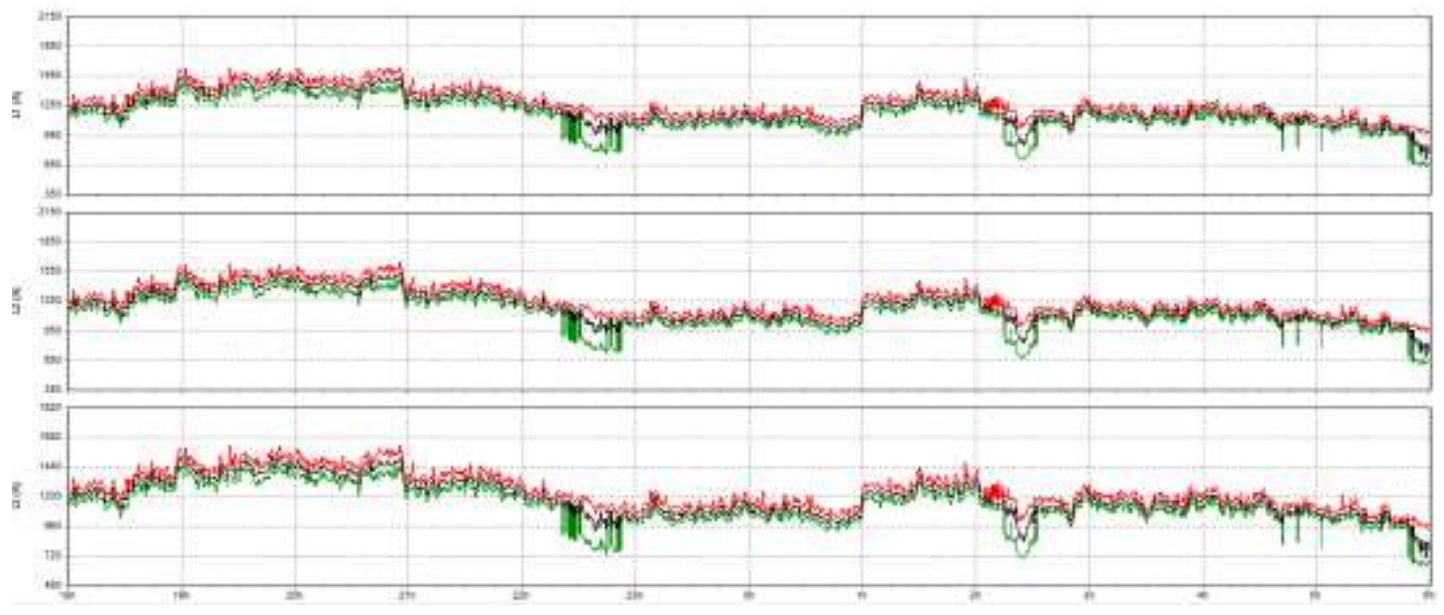

Fig. 3: Measurement of Current

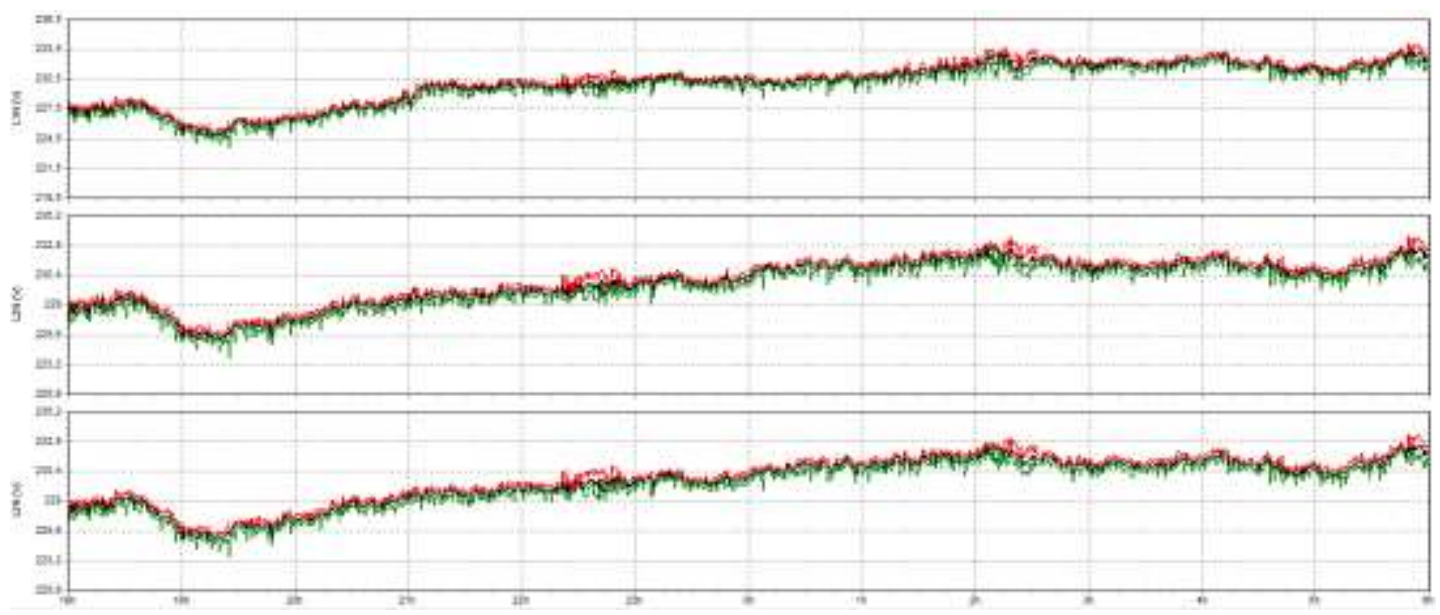

Fig. 4: Measurement of Voltage

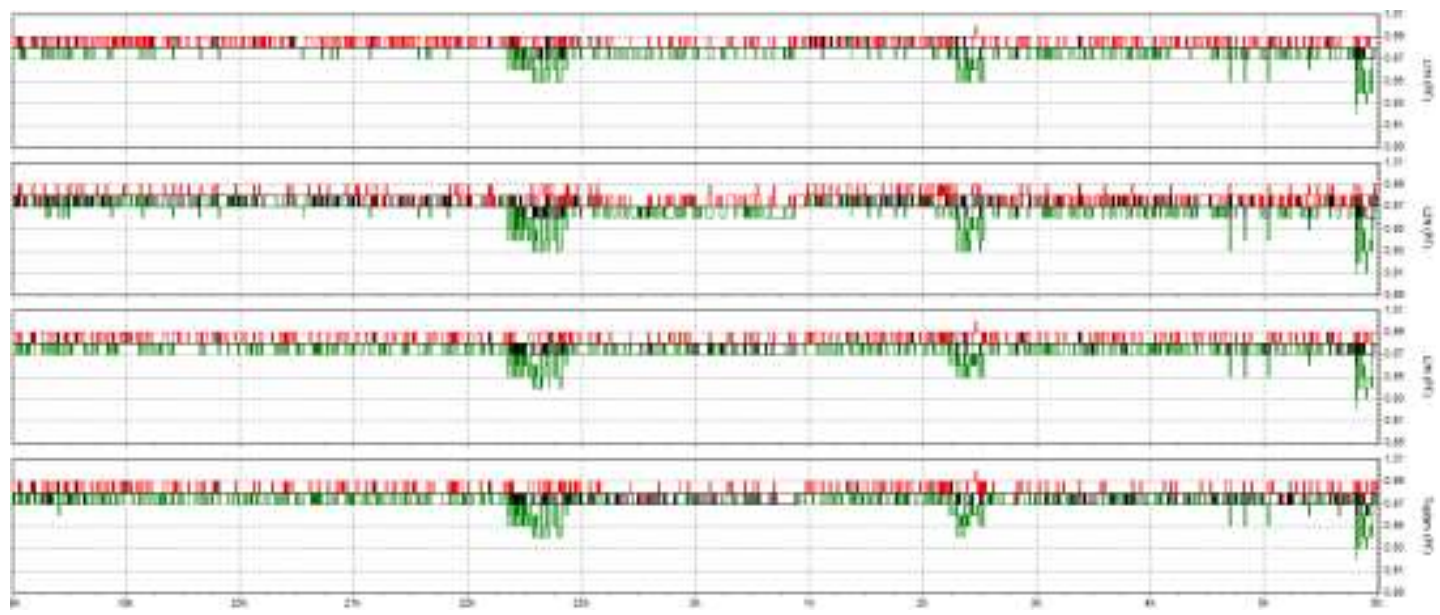

Fig. 5: Measurement of Power Factor 


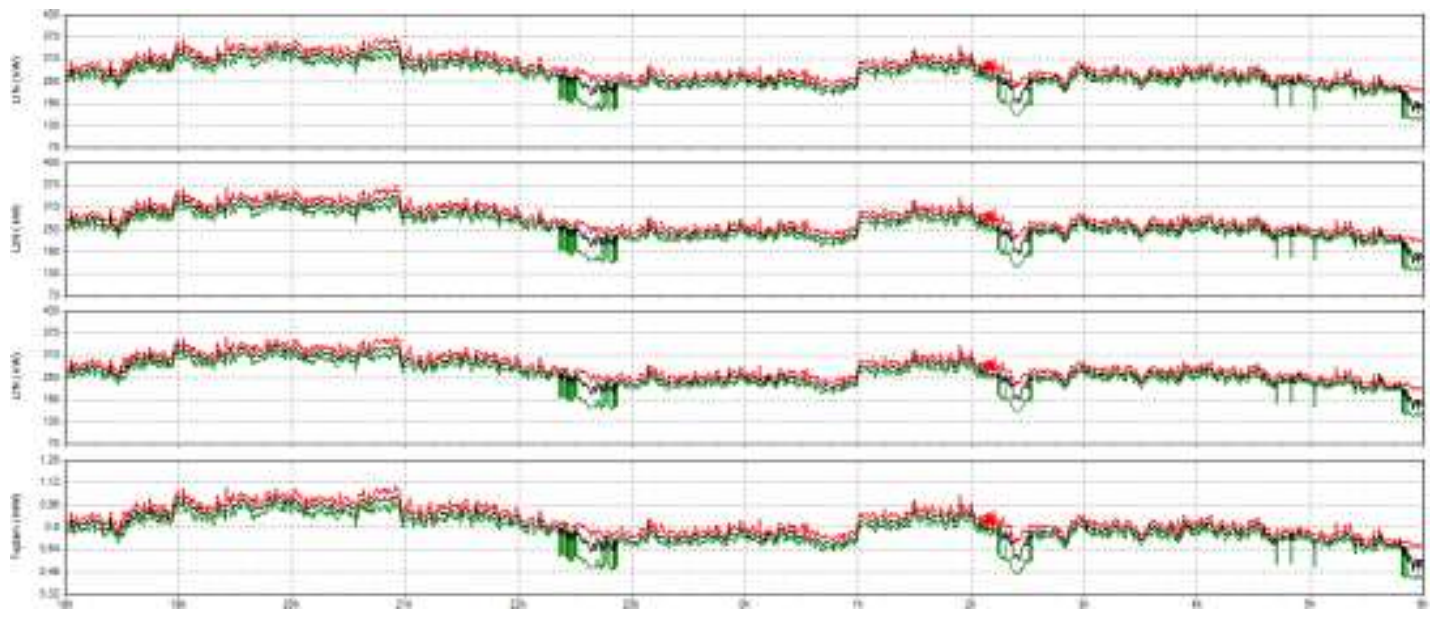

Fig. 6: Measurement of Power

\subsection{Measurement Results}

Matlab program is written to calculate the cost of the change of voltage, voltage harmonics, current harmonics and power factor. The data obtained from the industrial enterprises where the power quality measurement is performed are executed in matlab to calculate the industrial service cost of the power quality. The results are analyzed separately for each plant and the cost effect on total electricity usage, within the month and year when is performed, is calculated as a percentage.The cost of electricity depends on the unit cost of energy and energy consumption. Information on energy consumption and cost and the following values have emerged from the calculations for each facility. Cost is calculated as Turkish money unit lira TL.

TABLE II: The ratio of the energy quality of the industrial plants engaged in food production to the consumption of electric energy

\begin{tabular}{|c|c|c|c|c|c|c|c|}
\hline & $\begin{array}{l}\text { Annual Electricity } \\
\text { Consumption } \\
(\mathrm{kWh})\end{array}$ & $\begin{array}{l}\text { Annual } \\
\text { Electricity } \\
\text { Consumptio } \\
\mathrm{n}(\mathrm{TL})\end{array}$ & $\begin{array}{l}\text { Monthly } \\
\text { Electricity } \\
\text { Consumptio } \\
\mathrm{n}(\mathrm{kWh}) \\
\end{array}$ & $\begin{array}{l}\text { Monthly } \\
\text { Electricity } \\
\text { Consumptio } \\
\text { n (TL) }\end{array}$ & $\begin{array}{l}\text { Annual Cost for } \\
\text { poor power quality } \\
\text { (TL) }\end{array}$ & $\begin{array}{l}\text { Monthly Cost for } \\
\text { poor power quality }\end{array}$ & $\begin{array}{l}\text { Monthly } \\
\text { cost to total } \\
\text { financial } \\
\text { ratio }\end{array}$ \\
\hline 1.Facility & 14.426 .905 & 3.194 .935 & 1.286 .484 & 282.762 & 7.200 & 600 & $\% 0,21$ \\
\hline 2.Facility & 40.804 .102 & 9.858 .078 & 3.227 .271 & 780.519 & 9.811 & 818 & $\% 0,10$ \\
\hline 3.Facility & 12.843 .256 & 2.953 .949 & 1.107 .791 & 254.792 & 55.632 & 4.636 & $\% 1,82$ \\
\hline
\end{tabular}

TABLE III: The ratio of the energy quality of the industrial plants engaged in building material production to the consumption of electric energy

\begin{tabular}{|c|c|c|c|c|c|c|c|}
\hline & $\begin{array}{l}\text { Annual } \\
\text { Electricity } \\
\text { Consumption } \\
\text { (kWh) }\end{array}$ & $\begin{array}{l}\text { Annual } \\
\text { Electricity } \\
\text { Consumption } \\
\text { (TL) }\end{array}$ & $\begin{array}{l}\text { Monthly } \\
\text { Electricity } \\
\text { Consumption } \\
\text { (kWh) }\end{array}$ & $\begin{array}{l}\text { Monthly } \\
\text { Electricity } \\
\text { Consumption } \\
\text { (TL) }\end{array}$ & $\begin{array}{l}\text { Annual Cost for } \\
\text { poor power } \\
\text { quality (TL) }\end{array}$ & $\begin{array}{l}\text { Monthly Cost for } \\
\text { poor power } \\
\text { quality }\end{array}$ & $\begin{array}{l}\text { Monthly } \\
\text { cost to } \\
\text { total } \\
\text { financial } \\
\text { ratio }\end{array}$ \\
\hline 4.Facility & 20.301 .206 & 3.797 .773 & 1.703 .230 & 316.102 & 2.076 & 173 & $\% 0,05$ \\
\hline 5.Facility & 11.464 .208 & 2.863 .082 & 1.099 .779 & 274.502 & 1.176 & 98 & $\% 0,04$ \\
\hline
\end{tabular}


TABLE IV: The ratio of the energy quality of the industrial plants engaged in paper production to the consumption of electric energy

\begin{tabular}{llllllll}
\hline \hline & $\begin{array}{l}\text { Annual } \\
\text { Electricity } \\
\text { Consumption } \\
(\mathrm{kWh})\end{array}$ & $\begin{array}{l}\text { Annual } \\
\text { Electricity } \\
\text { Consumption } \\
(\mathrm{TL})\end{array}$ & $\begin{array}{l}\text { Monthly } \\
\text { Electricity } \\
\text { Consumption } \\
(\mathrm{kWh})\end{array}$ & $\begin{array}{l}\text { Monthly } \\
\text { Electricity } \\
\text { Consumption } \\
(\mathrm{TL})\end{array}$ & $\begin{array}{l}\text { Annual Cost for } \\
\text { poor power } \\
\text { quality (TL) }\end{array}$ & $\begin{array}{l}\text { Monthly Cost } \\
\text { for poor power } \\
\text { quality }\end{array}$ & $\begin{array}{l}\text { Monthly } \\
\text { cost } \\
\text { total } \\
\text { financial } \\
\text { ratio }\end{array}$ \\
\hline 6.Facility & 1.975 .343 & 483.246 & 269.552 & 65.729 & 56.424 & 4.702 & $\% 7,15$ \\
7.Facility & 16.935 .680 & 3.946 .100 & 1.310 .610 & 313.043 & 0 & 0 & $\% 0$ \\
8.Facility & 58.388 .200 & 12.845 .404 & 4.533 .100 & 997.282 & 780 & 65 & $\% 0,01$ \\
\hline
\end{tabular}

TABLE V: The ratio of the energy quality of the industrial plants engaged in food production to the consumption of electric energy

\begin{tabular}{llllllll}
\hline \hline & $\begin{array}{l}\text { Annual } \\
\text { Electricity } \\
\text { Consumption } \\
(\mathrm{kWh})\end{array}$ & $\begin{array}{l}\text { Annual } \\
\text { Electricity } \\
\text { Consumption } \\
(\mathrm{TL})\end{array}$ & $\begin{array}{l}\text { Monthly } \\
\text { Electricity } \\
\text { Consumption } \\
(\mathrm{kWh})\end{array}$ & $\begin{array}{l}\text { Monthly } \\
\text { Electricity } \\
\text { Consumption } \\
(\mathrm{TL})\end{array}$ & $\begin{array}{l}\text { Annual Cost } \\
\text { for poor power } \\
\text { quality (TL) }\end{array}$ & $\begin{array}{l}\text { Monthly Cost } \\
\text { for poor power } \\
\text { quality }\end{array}$ & $\begin{array}{l}\text { Monthly } \\
\text { cost } \\
\text { total } \\
\text { financial } \\
\text { ratio }\end{array}$ \\
\hline 9.Facility & 21.024 .432 & 5.145 .846 & 1.986 .206 & 479.611 & 19.572 & 1.646 & $\% 0,34$ \\
10.Facility & 16.938 .190 & 3.865 .475 & 1.419 .192 & 348.229 & 39.528 & 3.294 & $\% 0,95$ \\
\hline
\end{tabular}

\section{Conclusion}

The results have revealed that there is a need to raise awareness of the power quality of industrial plants. It is needed to consider energy efficiency applications, especially for some installations. According to the results, the costs experienced due to power failures are low, as high cost losses are taken into account. While production is continuing the use of UPS and generators are increases. Although this is an extra cost for the plant, it is ignored when the glitch in production is taken into account.

When the power factor is examined, it is seen that there is no need for any criminal proceedings on a monthly basis, even though the time limits are exceeded. This is due to the criminal procedures resulting from the regulations as mentioned frequently in the thesis.

Though the voltage changes are generally within the limit values, it is seen that the limit values are exceeded at some time. Although the cost of power generated by this change for industrial enterprises is at very low levels, the distress caused by the equipment is more important.

Examination of harmonics is based on two bases, current and voltage harmonics. As can be seen from the analysis results, it is seen that harmonics cause serious cost losses especially for some industrial plants.

\section{References}

[1] Harmonics (electricalpower)."Wikipedia, TheFree Encyclopedia. Wikimedia Foundation, Inc. 4 April 2011. 5 April 2011.

[2] LaCommare, K. H. \&Eto, J. H. "Cost of PowerInterruptionstoElectricityConsumers in the United States (US)", Energy, Volume 31, Issue 12, Pp. 1845-1855.2013.

[3] Sullivan, M.J.,Vardell, T., \& Johnson M."PowerInterruptionCoststoIndustrialand Commercial Consumers of Electricty”, IEEE Transactions on Industry Applications. Volume 33, Issue 6, Pp. 1448-1458, 1997.

https://doi.org/10.1109/28.649955 
[4] Zhong, Q.,Huang, W., Thao, S. \&Xiao, X."Survey on Assessment of PowerQualityCost in ShanghaiChina”, IEEE PES General Meeting, (Pp. 1 - 5). Jul 27-31, 2014.

[5] Zhao, Yiting. ElectricalPowerSystems Quality, University at Buffalo, 2006

[6] Vannoy, D.B.,McGranaghan, M.F., Halpin, S.M., Mancrief, W.A. \& Sabin D.“RoadmapforPower-QualityStandarts Development”, IEEE Transactions on Industry Applications. Volume 43, Issue 2, Pp. 412-421, 2007. https://doi.org/10.1109/TIA.2006.890017

[7] IEEE Std 519-1992, IEEE RecommendedPracticesandRequirementsforHarmonic Control in ElectricalPowerSystems, New York, 1992.

[8] Lin, Z.,Li, G., Zhou, M. \&Lo, L. "Economic Evaluation of Real-Time PowerQualityCost"PowerEngineering Conference (UPEC), (Pp. 1 - 5). 2011.

[9] Vegunta, S.C.\&Milanovic, J.V.“Estimation of Cost of Downtime of IndustrialProcessDuetoVoltageSags”, IEEE Transactions on Power Delivery. Volume 26, Issue 2, Pp. 576-587, 2014.

[10] Abdur-Razzaq, M.,Auckland, D. W., Chandraker, K., and.Varlow, B. R., "FrequencyandFieldRoles in WaterAbsorbatin in CompositeDielectrics" The 7th International Conference on DielectricMaterials, Measurementsand Application, Bath, United Kingdom, 23-16 September, 1996. 